\title{
PERTANIAN
}

\section{PENGARUH JENIS AUKSIN TERHADAP PEMBENTUKAN KALUS DAN DAYA REGENERASI TIGA VARIETAS PADI LOKAL}

\author{
The Influence of Auxin Types for Callus Induction and Plant Regeneration \\ of Three Local Rice Varieties
}

\section{Zaiyin Rizky Ageng Maulidia dan Wahyu Indra Duwi Fanata*}

\author{
Program Studi Agroteknologi, Fakultas Pertanian, Universitas Jember \\ Jalan Kalimantan 37, Kampus Tegal Boto Jember 68121 \\ *E-mail: wahyuindra.faperta@unej.ac.id
}

\begin{abstract}
Indonesia is rich in rice genetic diversity in the form of javanica rice. Subspecies javanica have some superiority characters, among others a strong plant tissue, but in generally they have low productivity. Weaknesses of javanica rice can be repaired by biotechnology through genetic transformation techniques from callus of plant. Auxin types and genotypes are important factors for callus induction and plant regeneration. Therefore, this research held for know callus introduction and plant regeneration of three varieties of Javanica rice (Pendok, Genjah Arum, and Menthik Wangi Susu) combined with type of auxin (2,4-D and pychloram). The experimental design of RALs two factorials, there are three varieties of rice (Pendok, Genjah Arum, and Menthik Wangi Susu) and two types of auxin (2,4-D and Pychloram) and analyzed by DMRT $\alpha 5 \%$. The results of this study is Mentik Wangi Susu have highest regeneration than Pendok and Genjah Arum. The use of 2,4-D resulted in a higher callus induction and plant regeneration than pychloram in the three rice varieties used. While the best combination of treatments for callus induction and regeneration is Menthik Wangi Susu and 2,4-D.
\end{abstract}

Keyword: auxin, javanica, callus induction, plant regeneration.

\begin{abstract}
ABSTRAK
Indonesia kaya akan keragaman genetik padi berupa padi javanica. Padi sub spesies javanica memiliki beberapa keunggulan diantaranya jaringan tanaman yang kuat, namun pada umumnya mempunyai tingkat produktivitas gabah yang rendah. Kelemahan pada padi javanica dapat diperbaiki dengan bioteknologi melalui teknik transformasi genetik menggunakan jaringan kalus. Genotip dan jenis auksin merupakan faktor penting dalam induksi kalus dan regenerasi tanaman padi secara in vitro. Oleh karena itu, penelitian ini dilaksanakan untuk mengetahui daya pembentukan kalus dan regenerasi pada tiga varietas padi javanica, yaitu Pendok, Genjah Arum, dan Menthik Wangi Susu yang dikombinasikan dengan perlakuan jenis auksin berupa penggunaan 2,4-D dan pikloram. Rancangan percobaan yang digunakan adalah RAL dua faktorial yaitu varietas tanaman padi dan jenis auksin dengan pengujian menggunakan DMRT $\alpha 5 \%$. Hasil penelitian menunjukkan bahwa dari ketiga varietas padi yang digunakan, varietas Mentik Wangi Susu menunjukan daya regenerasi yang tertinggi dibandingkan varietas Pendok dan Genjah Arum. Penggunaan 2,4-D menghasilkan tingkat pengkalusan dan regenerasi yang tinggi dibandingkan pikloram pada tiga varietas padi yang digunakan. Sedangkan kombinasi perlakuan yang terbaik untuk induksi kalus dan daya regenerasi adalah penggunaan varietas Menthik Wangi Susu dan auksin dalam bentuk 2,4-D.
\end{abstract}

Kata Kunci: auksin, javanica, induksi kalus, regenerasi tanaman.

How to citate: Maulidia, Z. R. A dan W. I. D. Fanata. 2019. Pengaruh Jenis Auksin terhadap Pembentukan Kalus dan Daya Regenerasi Tiga Varietas Padi Lokal. Berkala Ilmiah Pertanian, 2(2): 77-81.

\section{PENDAHULUAN}

Negara-negara di Benua Asia menjadikan padi sebagai tanaman pokok sehingga produksi padi setiap tahunnya sangat diperhatikan, pada tahun 2010 Asia mampu memproduksi padi sebesar 0,32-197,2 miliar ton pada tahun 2010 dengan produksi perkapita penduduk sebesar $152 \mathrm{~kg}$ (FAO, 2012). Namun produksi padi tersebut tidak merata di seluruh negara di benua Asia. Produksi padi di benua Asia didominasi oleh Thailand, Vietnam, Filipina, Myanmar, dan Indonesia. Hal ini disebabkan adanya perbedaan kondisi wilayah, sistem pertanian, kondisi iklim, dan kebijakan dari negara masing-masing. Indonesia dinilai memiliki kesesuaian iklim dan kondisi lahan dengan tanaman padi, selain Thailand dan Vietnam yang memiliki produksi padi lebih tinggi. Namun, produksi padi di Indonesia tidak dapat dikatakan stabil seperti negara lain di benua Asia.
Pada rentang tahun 2010-2015 Indonesia mengalami perkembangan produksi padi yang fluktuatif dan terjadi ketidakseimbangan antara produksi dan konsumsi beras penduduk Indonesia. Berdasarkan data dari Badan Pusat Statistik (2016) diketahui bahwa produksi padi nasional sebesar 66.469.394 ton pada tahun $2010 ; 65.756904$ ton tahun $2011 ; 69.056 .126$ ton pada tahun $2012 ; 71.279 .709$ ton pada tahun $2013 ; 70.846 .465$ ton pada tahun 2014; dan 75.397.841 ton pada tahun 2015; sedangkan berdasarkan data dari Badan Pusat Statistik (2017) rata-rata konsumsi beras per kapita per minggu adalah $1.755 \mathrm{~kg}$ pada tahun $2010,1.721 \mathrm{~kg}$ pada tahun $2011,1.675 \mathrm{~kg}$ pada tahun 2012, 1.642 pada tahun 2013, 1.626 $\mathrm{kg}$ pada tahun 2014, dan $1.631 \mathrm{~kg}$ pada tahun 2015. Adanya ketidakseimbangan ini menyebabkan Indonesia mengalami kekurangan persediaan beras pada rentang tahun 2010-2015. Penurunan produksi tertinggi terjadi pada tahun 2015 sebesar 4.551.376 ton, hal ini diikuti dengan kenaikan konsumsi beras sebesar 
$5 \mathrm{~kg}$ per kapita. Berbagai upaya dilakukan untuk memenuhi kebutuhan beras sebagai makanan pokok, salah satunya dengan melakukan impor beras. Pada tahun 2015 Indonesia menjadi salah satu negara pengimpor beras tertinggi di Asia yang mencapai 861.601 ton pada tahun 2015 (BPS, 2017).

Tanaman padi merupakan salah satu jenis tanaman pangan utama di Indonesia. Tanaman padi memiliki pembagian taksonomi sebagai berikut: termasuk dalam keluarga Gramineae (Siregar, 1981), genus Oryzae dan termasuk dalam ordo Poaceae (Sharma et al., 2017). Tanaman padi merupakan tanaman pangan di Indonesia yang terdiri dari tiga ras antara lain ras sinika atau japonika, ras indica dan ras javanika (sub-japonika). Subspesies japonika terdiri dari Temperate dan Tropical Japonika (Javanika). Sebagian besar subspesies Tropical Japonika atau Javanika merupakan varietas lokal yang berkembang di Indonesia dengan jumlah lebih dari 8000 varietas dan tersebar di seluruh daerah. Setiap ras tanaman padi memiliki ciri khas masing-masing yang membedakan satu dengan yang lain.Ciri umum varietas lokal Indonesia antara lain memiliki malai panjang, anakan sedikit, biji bulat dan susah rontok, daun lebar, membutuhkan fotoperiode yang intensif, kandungan amilosa intermediet (Sobrizal, 2016). Berikut merupakan pembagian ras tanaman padi menurut Chang, 1988:

\section{Ras Japonika}

Ras Japonika memiliki morfologi daun lebar berwarna hijau muda dengan bentuk gabah panjang dan ramping. Umumnya tanaman padi ras Japonika memiliki btang yang tinggi, jaringan tanaman lembut dan kadar amilosa 23-31\%. Tanaman padi ras Japonika juga memiliki anakan yang banyak dan kebanyakan tanaman padi pada ras ini tidak berbulu.

\section{Ras Indica}

Ras indica memiliki morfologi daun tanaman sempit dan berwarna hijau tua. Bentuk gabah tanaman padi ini pendek dan bulat, memiliki tingkat anakan sedang. Umumnya tanaman padi ras indica tidak terlalu tinggi, memiliki bulu panjang, jaringan tanaman keras, dan kandungan amilosa $10-24 \%$.

3. Ras Javanika

Umumnya ras javanika memiliki morfologi daun lebar dan kaku, anakan sedikit, batang tinggi, serta ekor gabah panjang. Ras javanika kurang diminati untuk dibudidayakan karena spesifik lokasi dan produktivitasnya lebih rendah dibandingkan dengan dua ras tanaman padi yang lain, namun ras javanika memiliki kekuatan organ tanaman yang lebih baik daripada kedua ras tanaman padi sehingga memiliki tingkat kerontokan gabah yang sedikit dan jaringan keras sehingga tidak mudah terserang Organisme Pengganggu Tanaman. Kadar amilosa pada ras Javanika berkisar $20-25 \%$.

Tanaman padi Javanika merupakan ras padi berpotensi untuk dikembangkan di Indonesia. Tanaman padi javanika dapat tumbuh hampir di seluruh wilayah Indonesia karena kesesuaian iklim dan kondisi wilayah. Keunggulan tanaman ini memiliki jaringan yang kuat sehingga secara alami memiliki ketahanan diri terhadap serangan OPT yang dapat menurunkan hasil produksi. Adanya jaringan tanaman yang kuat juga mempermudah petani dalam perawatan setiap harinya dan menekan biaya input budidaya sehingga harga beras dapat dikendalikan. Namun, padi kelompok padi javanika kurang diminati petani karena produksinya yang rendah.

Peningkatan produksi tanaman padi Javanika dapat dilakukan melalui bioteknologi pertanian. Dalam bioteknologi dikenal teknik genome editing untuk memperbaiki sifat tanaman. Metode genome aditing memanfaatkan kalus sebagai obyek dalam mengubah susunan genetik tanaman agar memiliki sifat unggul yang lebih baik. Kalus adalah salah satu wujud dari dediferensiasi dan menjadi tahapan penting dalam budidaya in vitro. Pembentukan kalus dipengaruhi oleh bagian tanaman yang digunakan sebagai eksplan, metode budidaya in vitro yang digunakan, dan komposisi media tumbuh sebagai sumber nutrisi (Suryowinoto, 1996). Tanaman akan membentuk kalus dalam kondisi lingkungan tertentu. Kalus yang terbentuk berfungsi sebagai objek tranformasi atau modifikasi gen untuk perbaikan sifat tanaman. Setiap kalus yang digunakan harus memiliki kemampuan regenerasi menjadi tanaman baru sehingga didapatkan tanaman padi dengan sifat unggul yang baru. Menurut Lestari (2011) keberhasilan pembentukan kalus dan regenerasi dipengaruhi oleh berbagai faktor antara lain media kultur, genotipe tanaman, dan keadaan fisiologi eksplan. Kalus yang mampu beregenerasi merupakan kalus yang bersifat embrioid. Berdasarkan hasil penelitian Ho dan Vasil (1983), kalus dapat diklasifikasikan menjadi tiga kelompok yaitu kalus kompak, kalus remah, dan kalus berlendir. Kalus yang bersifat embrioid memiliki ciri-ciri bentuk bulat kompak dan berwarna putih.

Genetik tanaman dan jenis zat pengatur tumbuh merupakan faktor penting dalam pembentukan kalus dan daya regenerasi tanaman. Zat pengatur tumbuh auksin dalam media induksi kalus akan memacu pembentukan kalus. Ada beberapa jenis auksin antara lain IAA, 2,4-D, pychloram dan NAA. Aktivitas auksin dipengaruhi oleh adanya struktur cincin yang tidak jenuh, adanya rantai keasaman (acid chain), pemisahan gugus karboksil (-COOH) dan struktur cincin, serta adanya pengaturan ruangan antar struktur cincin dengan rantai keasaman (Abidin, 1989). Sedangkan setiap genetik tanaman memiliki respon yang berbeda terhadap pemberian jenis auksin tertentu. Kombinasi antara genetik tanaman dan jenis zat pengatur tumbuh memberikan pengaruh dalam pembentukan kalus dan daya regenerasinya. Hal ini akan membawa banyak keuntungan dalam bidang pemuliaan tanaman dan bioteknologi, dimana kalus menjadi obyek dalam memperbaiki sifat tanaman. Oleh karena itu, penelitian ini dilakukan untuk mengetahui pengaruh jenis zat pengatur tumbuh auksin dan genetik tanaman padi javanika terhadap pembentukan kalus dan daya regenerasinya.

\section{BAHAN DAN METODE}

Penelitian dilaksanakan pada bulan April 2018 sampai dengan bulan Agustus 2018 di Laboratorium Kultur Jaringan Tanaman, Center for Development of Advance Science and Technology (CDAST) Universitas Jember. Rancangan percobaan menggunakan Rancangan Acak Lengkap (RAL) dua faktorial yaitu tiga varietas tanaman padi Javanika (V1=Pendok, V2 $=$ Genjah Arum, V3=Menthik Wangi Susu) dan Jenis Auksin (A1=2,4-D, A2=Pychloram). Setiap kombinasi perlakuan diulang sebanyak tiga kali sehingga didapatkan 18 satuan percobaan.

Prosedur Pelaksanaan terdiri dari beberapa tahap antara lain sterilisasi alat dan ruang, pembuatan media induksi, persiapan eksplan, penanaman eksplan, pengamatan induksi kalus, pembuatan media regenerasi, tahap regenerasi dan pengamatan regenerasi. Sterilisasi alat meliputi alat diseksi dan glassware menggunakan autoclave $121^{\circ} \mathrm{C}$ dengan tekanan 17,5 psi selama $15-20$ menit. Sedangkan sterilisasi ruang menggunakan alkohol $70 \%$ dan penyinaran UV selama 30-60 menit. Pembuatan media induksi dilakukan sebagai persiapan tanaman. Media induksi kalus menggunakan media padat N6 dan ditambahkan jenis auksin yang sesuai dengan perlakuan. $\mathrm{pH}$ media 5,8 dengan banyak media 20 $\mathrm{ml} /$ petridish. Media disterilkan menggunakan autoclave dengan suhu $121^{\circ} \mathrm{C}$ dan tekanan 17,5 psi selama $15-20$ menit. Setelah pembuatan media, eksplan tanaman mulai dipersiapkan. Eksplan tanaman untuk induksi kalus adalah bemih tanaman padi yang telah terpisah dari kulitnya. Benih disterilisasi dengan mengocoknya pada larutan hipoklorit 25\% selama 20-30 menit dan dibilas menggunakan aquades steril hingga bersih, dan dikeringkan di atas kertas saring di dalam petridish. Eksplan ditanaman di media induksi kalus selama 14 hari pada di dalam inkubator dengan suhu $28-30^{\circ} \mathrm{C}$. Pengamatan induksi kalus dilakukan setiap tiga hari sekali untuk mengamati perkembangan kalus. Pengamatan yang dilakukan meliputi kondisi benih, pembengkakan skutelum, pembentukan tunas, dan pembentukan kalus. Variabel pembentukan kalus didapat dari banyaknya kalus yang terbentuk sampai 14 hari setelah penanaman. Sebelum kalus berumur 14 hari, dilakukan pembuatan media regenerasi. Media regenerasi menggunakan media padat N6 dengan penambahan $\mathrm{Fe}_{2}$ EDTA, kinetin $3 \mathrm{ppm}$ dan NAA 0,5 ppm. pH media 5,8 sebanyak $25 \mathrm{ml} /$ petridish. Media disterilkan menggunakan autoclave dengan suhu $121^{\circ} \mathrm{C}$ dan tekanan 17,5 psi selama $15-20$ menit. Regenerasi dilakukan setelah induksi kalus selama 14 hari. Kalus yang terbentuk dipindahkan ke dalam media regenerasi, kemudian disimpan di dalam chamber agar kalus mendapat cahaya yang mencukupi. Pengamatan regenerasi dilaksanakan mulai 15 hari setelah tanam sampai 42 hari setelah tanam. Pengamatan regenerasi meliputi persentase pembentukan spot hijau dan persentase regenerasi, 
dimana dapat dikatakan regenerasi bila kalus sudah terdeferensiasi menjadi bagian-bagian tanaman (akar, batang, daun).

Variabel pengamatan. terdiri dari struktur dan warna kalus, persentase induksi kalus (\%), persentase pembentukan spot hijau (\%), persentase regenerasi (\%).

\section{HASIL DAN PEMBAHASAN}

\section{Persentase Induksi Kalus}

Hasil penelitian menunjukkan kalus dari enam kombinasi perlakuan memiliki kenampakan fisik yang berbeda-beda (Gambar 1). Media induksi kalus yang mengandung 2,4-D menghasilkan kalus yang remah, berwarna putih kekuningan, dan granul (Gambar 1 a-c). Sedangkan pemberian Pychloram dalam media induksi menghasilkan kalus yang putih kekuningan, tidak granul, dan tidak remah (Gambar 1 d-f). Pemberian Pychloram pada media induksi kalus di semua varietas memacu pertumbuhan tunas terlebih dahulu sehingga menghambat pembentukan kalus yang optimal. Hal tersebut berpengaruh pada pembentukan kalus embrioid untuk regenerasi. Kalus embrioid ditandai dengan bentuk bulat, kompak, dan berwarna putih (Minarsih dkk., 2016).
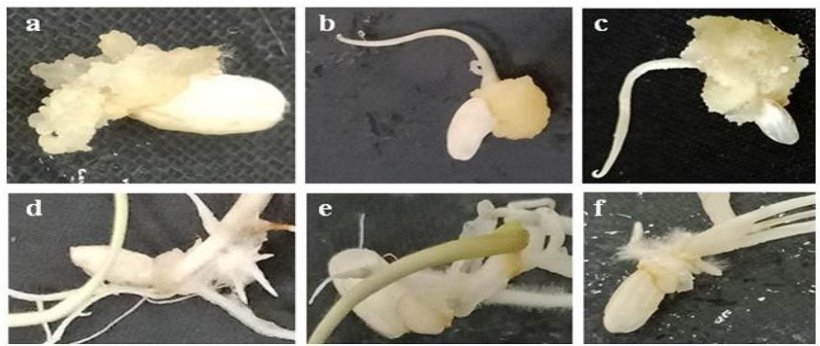

Gambar 1: Kenampakan Fisik Kalus (a) Pendok + 2,4-D; (b) Genjah Arum + 2,4-D; (c) Methik Wangi Susu + 2,4-D; (d) Pendok + Pychloram; (e) Genjah Arum + Pychloram; (f) Menthik Wangi Susu + Pychloram.

Gambar 2 menunjukkan persentase induksi kalus dari semua kombinasi perlakuan. Persentase induksi kalus tertinggi pada kombinasi perlakuan Genjah Arum dan 2,4-D dengan persentase kalus sebesar $100 \%$, sedangkan kombinasi perlakuan Menthik Wangi Susu dan Pychloram menunjukkan persentase kalus terendah sebesar $52,67 \%$. Persentase kalus terbaik ditunjukkan oleh penggunaan 2,4-D pada ketiga varietas dengan persentase sebesar $100 \%$ pada varietas Genjah Arum, 98,33\% pada varietas Pendok, dan 97,33\% pada varietas Menthik Wangi Susu. Hasil penelitian tersebut sesuai dengan hasil penelitian sebelumnya yang dilakukan oleh Benlioglu, et al. (2015), dimana media induksi kalus yang mengandung 2,4-D memberikan pengaruh persentase kalus yang lebih tinggi daripada media induksi kalus yang mengandung Pychloram.

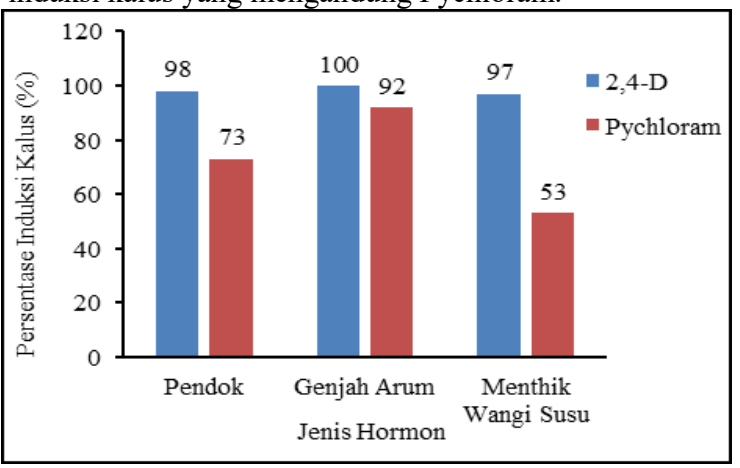

Gambar 2. Persentase Induksi Kalus dari Embrio Padi Varietas Pendok, Genjah Arum, dan Menthik Wangi Susu. Data merupakan nilai rata-rata $\pm \operatorname{SE}(n=3)$.

Pemberian 2,4-D menunjukkan persentase kalus tertinggi di setiap varietas bila dibandingkan dengan persentase kalus pada pemberian Pychloram. Rata-rata persentase kalus dengan pemberian 2,4-D sebesar 98,55\% sedangkan pada pemberian Pychloram sebesar 72,56\%. Zat pengatur tumbuh 2,4-D lebih efektif daripada Pychloram dalam memacu induksi kalus. dan regenerasi yang tinggi dalam kultur embrionik tanaman serealia (Benlioglu et al., 2015) optimum 2,4-D sebesar $2 \mathrm{mg} / \mathrm{L}$ untuk mendukung pembentukan kalus tertinggi tanaman padi (Upadhyaya et al., 2015). Perlakuan Pychloram menunjukkan bahwa adanya pengaruh yang berbeda pada varietas Genjah Arum dengan rata-rata persentase kalus tertinggi yaitu $92 \%$. Hal ini menunjukkan adanya pengaruh genotip tanaman dimana Genjah Arum memiliki respon pembentukan kalus tertinggi baik dengan pemberian 2,4-D maupun pychloram. Terdapat interaksi genotip dan zat pengatur tumbuh yang dapat mempengaruhi persentase induksi kalus, berat kalus, dan persentase regenerasi sehingga meningkatkan efisiensi kultur (Benlioglu et al., 2015).

Pengaruh genotip ditunjukkan oleh varietas Pendok dan Menthik Wangi Susu. Rata-rata persentase kalus varietas Pendok sebesar $85,67 \%$ dan persentase kalus pada varietas Menthik Wangi Susu sebesar $75 \%$. Induksi kalus dipengaruhi oleh konsentrasi 2,4-D yang optimum, sumber eksplan, dan genotip tanaman padi (Libin et al., 2012). Setiap tanaman akan merespon lingkungan dengan berbagai macam reaksi termasuk pembentukan induksi kalus. Hasil penelitian menunjukkan bahwa varietas Genjah Arum adalah varietas paling responsif untuk membentuk kalus dalam perbedaan kedua jenis hormon dibandingkan dua varietas yang lain, Pendok dan Menthik Wangi Susu.

\section{Persentase Pembentukan Spot Hijau}

Gambar 3 menunjukkan proses pembentukan spot hijau (green spot) pada kalus dalam media regenerasi. Kombinasi perlakuan Pendok dan 2,4-D berwarna hijau terang dan terdapat kalus yang sudah beregenerasi menjadi tanaman sempurna pada 26 HST (Gambar 3a), spot hijau semakin hijau dan kalus sedikit menguning pada 32 HST (Gambar 3b), pada 41 HST menunjukkan kalus berbah warna menjadi kuning kecokelatan dan beberap spot hijau berubah menjadi kecokelatan (Gambar 3c).

Pada kombinasi perlakuan Genjah Arum dan 2,4-D kalus berubah warna menjadi kuning kecokelatan, akar mulai tumbuh, dan spot hijau muncul di beberapa titik pada 26 HST (Gambar 3d). Spot hijau berubah menjadi kecokelatan pada 32 HST, warna kalus berubah menjadi kuning kecokelatan, dan terlihat deferensiasi menjadi daun (Gambar 3e). Pada umur 41 HST kalus berubah warna menjadi kecokelatan, serta perkembangan tanaman sudah sempurna, namun spot hijau berubah warna menjadi cokelat (Gambar 3f).

Kombinasi perlakuan Menthik Wangi Susu dan 2,4-D menunjukkan pembentukan spot hijau dan regenerasi terbaik pada 26 HST dengan warna spot hijau berwarna hijau terang serta beberapa kalus menunjukkan deferensiasi menjadi akar dan daun (Gambar 3g). Umur 32 HST kalus berubah warna menjadi kuning kecokelatan, spot hijau berwarna hijau tua, namun beberapa spot hijau menjadi kecokelatan (Gambar 3h). Pada 41 HST spot hijau menjadi hijau tua dan semakin gelap, beberapa kalus berubah warna menjadi cokelat serta kalus sudah beregenerasi sempurna (Gambar 3i). Regenerasi diinisiasi oleh pembentukan akar dan diikuti pembentukan spot hijau. Spot hijau akan semakin luas dan berwarna gelap kemudian terdeferensiasi. Spot hijau akan berlanjut dalam fase elongasi dan beregenerasi menjadi tanaman sempurna (Artadana et al., 2017).

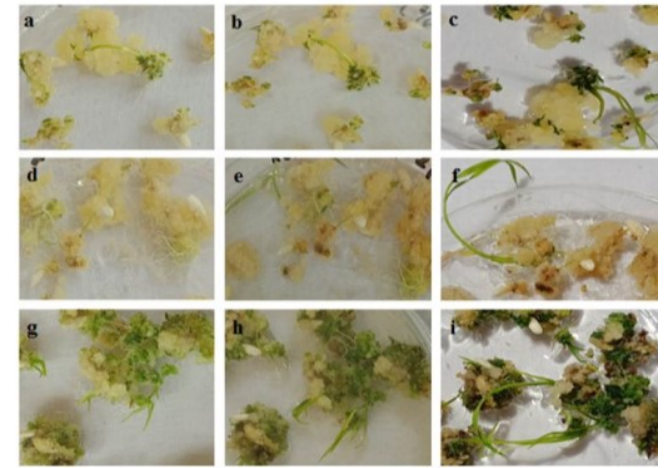

Gambar 3: Pembentukan Spot hijau pada Kalus (a) Pendok + 2,4-D 26 HST; (b) Pendok + 2,4-D 32 HST; (c) Pendok + 2,4-D 41 HST; (d) Genjah Arum + 2,4-D 26 HST; (e) Genjah Arum + 2,4-D 32 HST; (f) Genjah Arum + 2,4-D 41 HST; (g) Menthik Wangi Susu + 2,4-D 26 HST; (h) Menthik Wangi Susu + 2,4-D 32 HST; (i) Menthik Wangi Susu + 2,4-D 41 HST. 
Pada gambar 4 dapat diketahui persentase pembentukan spot hijau kalus dari tiga varietas tanaman padi. Proses pembentukan spot hijau kalus pada media regenerasi merupakan salah satu tanda kalus bersifat embrioid. Kombinasi perlakuan Menthik Wangi Susu dan 2,4$\mathrm{D}$ menunjukkan respon terbaik dalam proses pembentukan spot hijau dengan persentase sebesar $100 \%$, kemudian diikuti kombinasi perlakuan Pendok dan 2,4-D sebesar 36\% serta Genjah Arum dan 2,4D sebesar $34 \%$. Spot hijau adalah awal dari regenerasi kalus, daerah hijau akan berdeferensiasi menjadi organ tanaman seiring bertambahnya waktu (Artadana et al., 2017).

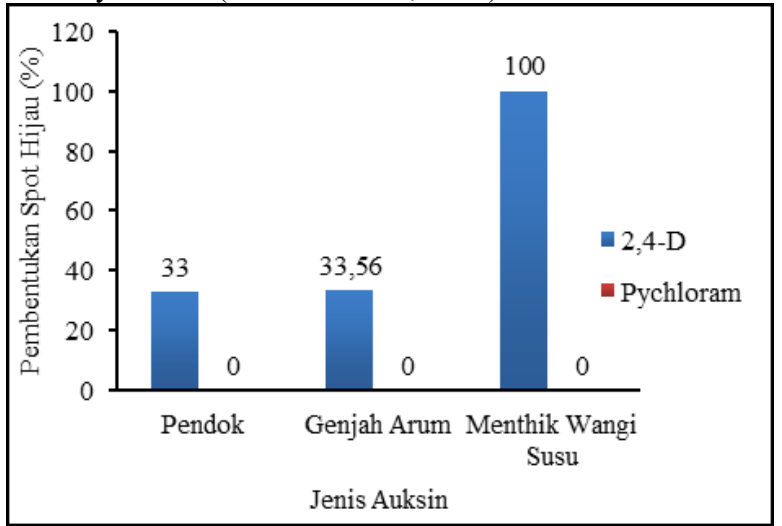

Gambar 4. Persentase Pembentukan spot hijau Kalus dari Embrio Padi Varietas Pendok, Genjah Arum, dan Menthik Wangi Susu. Data merupakan nilai rata-rata $(\mathrm{n}=3)$.

Zat pengatur tumbuh 2,4-D merupakan perlakuan jenis zat pengatur tumbuh terbaik dalam persentase pembentukan spot hijau. Keberhasilan pembentukan spot hijau merupakan awal dari regenerasi tanaman, dimana regenerasi diinisiasi oleh pembentukan akar yang diikuti oleh pembentukan spot hijau. Keberhasilan regenerasi dapat dipengaruhi beberapa faktor antara lain kombinasi jenis auksin dalam media regenerasi. Interaksi zat pengatur tumbuh auksin dan sitokinin dalam tanaman akan mempengaruhi diferensiasi sel dan morfogenesis sel tanaman (Artadana et al., 2017).

\section{Persentase Regenerasi}

Gambar 5 menunjukkan kemampuan regenerasi dari enam kombinasi perlakuan. Kalus yang berasal dari penambahan 2,4-D menunjukkan pertumbuhan regenerasi yang optimal dengan diawali oleh pembentukan spot hijau dan kemudian muncul organ-organ tanaman secara bertahap. Kalus yang berasal dari penambahan 2,4-D dalam media induksi mengalami perubahan warna menjadi sedikit kecokelatan (Gambar 5a-c), sedangkan kalus yang berasal dari penambahan Pychloram tidak dapat beregenerasi (Gambar 5d-f). Kalus yang berasal dari penambahan pychloram dalam media induksi tidak granul dan menunjukkan perubahan warna menjadi kecokelatan pada hari ke-10 regenerasi. Semakin bertambahnya hari, kalus yang berasal dari penambahan Pychloram dalam media induksi berubah menjadi kehitam disertai dengan menghitamnya akar (Gambar 5d-f).

Kemampuan regenerasi akan terjadi bila kalus yang digunakan besifat embrioid. Kalus embrioid memiliki ciri-ciri bentuk bulat, kompak, dan berwarna putih. Menurut hasil penelitian Ho dan Vasil (1983), kalus diklasifikasikan menjadi tiga tipe berdasarkan potensi morfogeniknya yaitu kalus kompak, kalus remah, dan kalus berlendir. Kalus kompak merupakan kalus embrioid dengan ciri rata-rata berukuran kecil, kompak dan lembut, dan termasuk sel sitoplasmik. Kondisi kalus embrioid ditunjukkan oleh kalus yang berasal dari penambahan 2,4-D pada media induksi kalus. Kalus varietas Pendok dan Menthik Wangi Susu berbentuk bulat dan granul dengan warna kekuningan, sedangkan pada kalus varietas Genjah Arum berwarna kekuningan dan granul. Warna kalus berubah menjadi kekuningan setelah 10 hari induksi kalus. Hal ini dikarenakan adanya variasi somaklonal yang terjadi akibat penggunaan 2,4-D dalam waktu lama. 2,4-D dalam media kultur in vitro dapat meningkatkan peluang terjadinya variasi genetik dan menghambat kemampuan tanaman beregenerasi sebagai akibat subkultur berulang-ulang (Minarsih dkk., 2016).
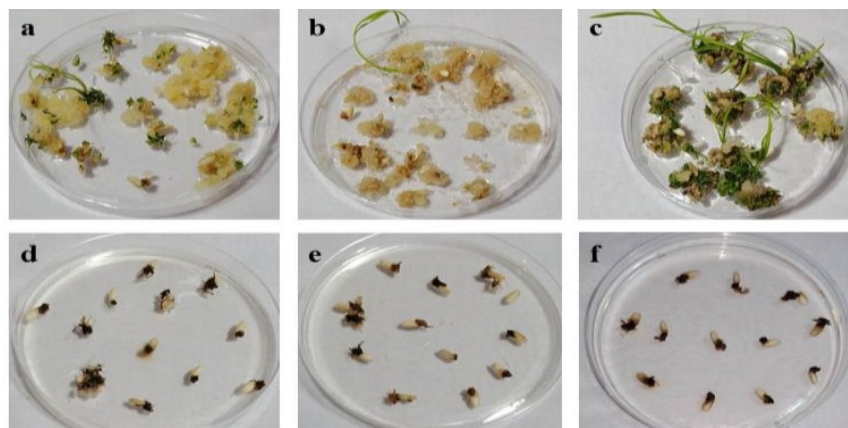

Gambar 5: Regenerasi Kalus (a) Pendok + 2,4-D; (b) Genjah Arum + 2,4-D; (c) Methik Wangi Susu + 2,4-D; (d) Pendok + Pychloram; (e) Genjah Arum + Pychloram; (f) Menthik Wangi Susu + Pychloram.

Gambar 6 merupakan persentase regenerasi yang menunjukkan bahwa persentase regenerasi tertinggi pada kombinasi perlakuan Menthik Wangi Susu dan 2,4-D sebesar 33\% sedangkan persentase terendah ditunjukkan oleh kombinasi perlakuan pychloram dengan semua varietas sebesar $0 \%$. Hasil penelitian sama dengan hasil penelitian yang dilakukan sebelumnya oleh Benlioglu et al. (2015), dimana persentase regenerasi kalus yang berasal dari media mengandung 2,4-D lebih tinggi daripada persentase regenerasi kalus dari media yeng mengandung Pychloram. Kalus dari media induksi yang mengandung 2,4-D merupakan kalus yang bersifat embrioid, sedangkan kalus dari media induksi yang mengandung Pychloram tidak bersifat embrioid sehingga tidak dapat beregenerasi.

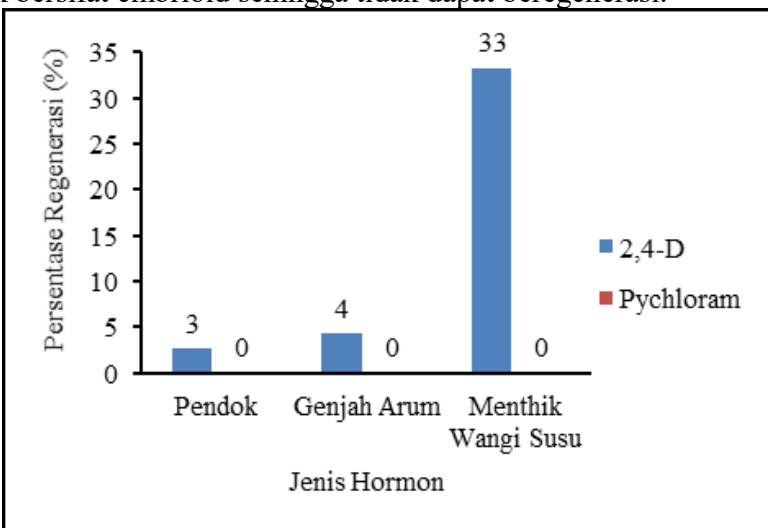

Gambar 6. Persentase Regenerasi Kalus dari Embrio Padi Varietas Pendok, Genjah Arum, dan Menthik Wangi Susu. Data merupakan nilai rata-rata $(n=3)$.

\section{KESIMPULAN}

Berdasarkan hasil penelitian yang telah dilakukan dan diuraikan, dapat disimpulkan bahwa terdapat perbedaan nyata kombinasi jenis auksin dan varietas padi Javanika terhadap pembentukan kalus dan daya regenerasi. Kombinasi perlakuan terbaik adalah Menthik Wangi Susu dan 2,4-D dengan persentase kalus sebesar $97,33 \%$ dan regenerasi sebesar $8,74 \%$.

\section{DAFTAR PUSTAKA}

Abidin, Z. 1989. Dasar-Dasar Pengetahuan tentang Zat Pengatur Tumbuh. Bandung: Penerbit Angkasa.

Artadana, I.B.M., G.B.F. Suhono, P.H Hardjo, M.G.M. Purwanto. Y.B. Wang, dan K. Supaibulwatana. 2017. Plant Regeneration Induced from Mature Embryo-derived Callus of Balinese Red Rice (Oryza sativa Cv. Barak Cenana). Bali Medical, 3(3): S12S17.

Benlioglu, B., D.E. Tuna, M.A. Birsin, and A.M Ozgen. 2015. Effect of Growth Regulators on Tissue Culture Parameters in Rice (Oryza sativa L.). Crop Breedings and Genetics, 1(2): 43-46. 
BKPPP Bantul. 2014. Data Kandungan Gizi Bahan Pangan dan Hasil Olahannya. Website resmi BKPPP Kabupaten Bantul Diakses $\begin{array}{llll}\text { pada } & 17 & \text { Oktober } & 2017\end{array}$ http://bkppp.bantulkab.go.id/filestorage/dokumen/2014/07/Data \%20Kandungan $\% 20$ Gizi $\% 20$ Bahan $\% 20$ Pangan $\% 20$ dan $\% 20 \mathrm{Ola}$ han.pdf.

BPS. 2016. Produksi Padi Menurut Provinsi (1993-2015). Website Resmi Badan Pusat Statistik diakses pada 13 Oktober 2017 di https://www.bps.go.id/linkTableDinamis/view/id/865.

BPS. 2017. Impor Beras Menurut Negara Asal Utama 2000-2015. Website Resmi Badan Pusat Statistik diakses pada 13 Oktober 2017 di https://www.bps.go.id/linkTabelStatis/view/id/1043.

BPS. 2017. Rata-Rata Konsumsi Per Kapita Seminggu Beberapa Macam Bahan Makanan Penting 2007-2015. Website resmi Badan Pusat Statistik diakses pada 17 Oktober 2017 di https://www.bps.go.id/linkTabelStatis/view/id/950.

Chang, T.T. 1984. The Ethnobotany of Rice in Island Southeast Asia. Asian Perspectives, 26(1): 69-76.

FAO. 2012. FAO Statistical Yearbook 2012. Roma: Food and Agriculture Ornization of The United Nations.

Genady, E.A.M. 2017. Influence of 2,4-D and Picloram in vitro Induction from Verbena bipinnatifida Nutt. And Evaluation of in vitro Anti-inflammatory Activity of Callus Extract. Basic and Applied Sciences, 11(2): 146-150.

Ho, W.J. and I.K.Vasil. 1983. Somatic Embryogenesis in Sugarcane (Saccharum officinarum L.) I. The Morphology and Physiology of Callus Fprmation and The Ontogeny of Somatic Embryos. Protoplasma, 118(1): 169-180.

Kaushal, L., S.M. Balachandran, K. Ulaganathan, and V, Shenoy. 2014. Effect of Culture Media on Improving Anther Culture Response of Rice (Oryza sativa L.). Agriculture Innovations and Research, 3(1): 2319-1473.

Lestari, E.G. 2011. Peranan Zat Pengatur Tumbuh dalam Perbanyakan Tanaman melalui Kultur Jaringan. Agrobiogen, 7(1): 63-68.

Lestari, E.G. dan R. Yunita. 2008. Induksi Kalus dan Regenerasi Tunas Padi Varietas Fatmawati. Agronomi, 36(2): 106-110.

Libin, A., P.J.H. King, K.H. Ong, J.K. Chubo, and P. Sipen. 2012. Callus Induction and Plant Regeneration of Sarawak Rice (Oryza sativa L.) Variety Biris. Agricultural Research, 7(30): 4260-4265.

Minarsih, H., Suharyo, I. Riyadi, dan D. Ratnadewi. 2016. Pengaruh Jumlah Subkultur dan Media Sub-optimal terhadap Pertumbuhan dan Kemampuan Regenerasi Kalus Tebu (Saccharum officinarum L.). Menara Perkebunan, 84(1): 28-40.

Sastrapradja, S.D. 2012. Perjalanan Panjang Tanaman Indonesia. Jakarta: Yayasan Pustaka Obor Indonesia.

Sharma, A., D. Lal, and M. Sutardhar. 2017. Effect of Growth Regulators on Callus Morphology of Rice Anther Culture. Aplied Biology and Biotechnoloby, 5(3): 68-71.

Siregar, H. 1981. Budidaya Tanaman Padi di Indonesia. Bogor: Sastra Hudaya.

Sobrizal. 2016. Potensi Pemuliaan Mutasi untuk Perbaikan Varietas Padi Lokal Indonesia. Aplikasi Isotop dan Radiasi, 12(1): 23-36.

Suryowinoto, M. 1996. Pemuliaan Tanaman secara In vitro. Yogyakarta: Penerbit Kanisius.
Taji, A., P.P.Kumar, dan P.Lakshmanan. 2005. Pemuliaan Tanaman Secara In Vitro. Terjemahan oleh Zulkarnain. Jambi: Universitas Jambi.

Upadhyaya, G., M. Sen, and A. Roy. 2015. In vitro Callus Induction and Plant Regeneration of Rice (Oryza sativa L.) var. 'Sita', 'Rupali' and 'Swarna Masuri'. Plant Science and Research, 5(5): 24-27.

Wetter, L.R. dan F. Constabel. 1982. Metode Kultur Jaringan Tanaman. Terjemahan oleh Dr. Mathilda B. Widianto dan Dr.Ir.Suminar Achmadi. 1991. Bandung: Penerbit ITB. 